\title{
FORESTRY IN NYASALAND
}

$\mathrm{F}$ ROM the annual report of the Forestry Department of the Nyasaland Protectorate for the year ending December 31, 1940 (Govt. Printer, Zomba, Nyasaland, 1941), it appears that a happy relationship has been established between that Department and the Agricultural Department. The Forestry Department has to some extent undertaken duties which bring it into direct relationship with the agricultural habits and practices of the local population. The Conservator reports that during the year the Provincial Agricultural Officer visited the southern course for special discussions, and the Director of Agriculture addressed the Foresters at the close of the course. These courses are annual ones given to the subordinate forest staff by divisional forest officers and lasting 10-14 days. The aims of the forestry policy in Nyasaland have been already discussed in NaTURE.

The formation of village forests has proved a most important departure in the Protectorate, for they have caught the imagination. It is stated that the number of registered village forest areas has now reached 4,677 and that the majority are well cared for by the headman and villagers. In some of the earliest formed, systematic thinnings are now being undertaken with assistance from the district forestry staffs. It will be noted that this management is on the same lines as practised in the management of the communal forests in France. But a still closer connexion between the forest staff and the agricul- tural community exists through the participation of the former in land use problems and in activities to introduce simple reforms in the agricultural methods of the people. It is said that results have been excellent in parts of the Southern Province and that whole communities have changed over from mound planting (on hill-sides, productive of serious erosion) to ridge planting on the contour. Hill slope closure and stream bank protection are serious questions in parts of the Protectorate, and a plea for increased agricultural production has emphasized the need for much better control by native authorities over the opening up of new land for cultivation. For example, one of the commonest phases of these unchecked, ignorant cultivation practices it is stated is that "in some regions very steep hill slopes, of only ephemeral utility for agriculture, are still being cleared for planting maize".

It appears only fair to a forest staff to point out that, so long as dangerous activities of this kind axe allowed by the administration to be practised unchecked, the danger to the Colony concerned as a whole may be so great as to render nugatory the efforts of a Department in obtaining sanction to the formation of forest reserves with a view to their professional management; or even to the future success of the village forests, to the inauguration of which the Conservator of Forests in Nyasaland has devoted. so much energy with such refreshing and creditable results.

\section{OXFORD MEETING OF THE WORLD CONGRESS OF FAITHS}

\author{
By Sir Francis Younghusband, K.C.S.I., K.C.I.E.
}

$\mathrm{R}$ ECONSTRUCTION is in the air : the need for building a New World Order; and the need for a sound spiritual basis on which to build it. This was the subject discussed at the meeting held at Oxford during June 27-July 2 of the World Congress of Faiths. The main idea of the Congress is to promote the spirit of fellowship and to promote it through religion; not through one religion only, but through all religions working in collaboration and in concert, each retaining its own individuality, its own special forms and beliefs, but all willing to work with others in the great world-reconstruction now before us.

With this as its general aim, the World Congress of Faiths had for its special-subject for discussion at this sixth annual meeting the interdependence of religion and the political, economic, social and educational aspects of the New World Order.

The Congress was officially welcomed to Oxford by the University. The inaugural meeting was addressed by the chairman of the Congress, Sir
Francis Younghusband, by Señor Madariaga, Sir Hassan Suhrawardy (Muslim adviser to the Secretary of State for India) and the Rev. Canon Grensted. Others who spoke at the sessions of the Congress included Lord Samuel, Dr. Gilbert Murray, Mr. Yussuf Ali (translator of the Koran into English), Lord Davies, Diwan Runganadhan (another Indian adviser to the Secretary of State for India), Baron Palmstierna (formerly Swedish Minister to the Court of St. James's), the Warden of All Souls, Prof. W. Adams, and Miss Maude Petre, a well-known Roman Catholic writer.

Both the addresses and the discussion on them were on a high level. As a result of the meeting it was decided to invite the principal leaders in the Hindu, Buddhist, Jewish, Confucian and Muslim worlds to make pronouncements so far as possible on similar lines to that issued by the Pope and acceded to by the leaders of the Roman Catholic, Anglican and Free Churches in Britain. But the Congress also passed a resolution advocating the addition of a 